\title{
A retrospective analysis of surgically managed adnexal masses in children and adolescents in a tertiary centre
}

\author{
Madhusmita Hembram, Haritha Sagili* and Papa Dasari \\ Department of obstetrics and Gynaecology, JIPMER, Pondicherry, India
}

\begin{abstract}
Aim: To study the clinical characteristics of adnexal masses in children and adolescents who were treated in our hospital from 2009-2013.

Materials and methods: We performed a retrospective analysis of adnexal masses in girls less than 20 years of age. Medical records were reviewed for symptoms, tumour markers, origin /size of the masses, treatment, histopathology and outcome. Data management and descriptive analysis were performed using SPSS 16.0.

Results: A total of 58 patients were included in the study. $87 \%$ of girls were postmenarchal, (7\%) were hypothyroid and 57 were elective admissions. The most frequent symptoms were abdominal pain (82\%), swelling (16\%) and menstrual disorders (2\%).Tumour markers -either LDH, CA - 125 , CEA or $\beta$ hCG were abnormal in $12 \%$. Size of tumour varied from $5-35 \mathrm{~cm}$. The origin of adnexal mass was ovarian in $92 \%$ and paraovarian in $8 \%$. The operations included laparoscopy in 13 cases and laparotomy in 45 cases. The type of surgery performed was ovarian cystectomy (15\%), paraovarian cystectomy (8\%), oophorectomy (35\%) and salpingoopherectomy (38\%). 2 girls had bilateral masses -frozen section showed immature teratoma, one underwent TAH+BSO and other girl had bilateral ovariotomy done. Ovarian torsion was seen in $25 \%$ of cases. Histopathological examination revealed 23 functional lesions, 33 benign and 2 malignant masses. One girl was diagnosed with hydatid cyst intraoperatively and was started on Albendazole. Postoperative course was uneventful in all cases.
\end{abstract}

Conclusion: Adnexal masses are relatively uncommon in children and adolescents. Minimal invasive surgery targeting fertility preservation is recommended in managing these adnexal masses.

\section{Introduction}

Adolescent ovarian tumours are uncommon tumours comprising $<2 \%$ of ovarian tumours [1]. Due to its relatively lower incidence, general gynaecologists are not very familiar with the clinical features and management. In this study we retrospectively analysed children and adolescents who underwent surgery for adnexal masses.

\section{Methods}

Our cohort included 58 children and adolescents who underwent surgery for adnexal masses in a tertiary care referral hospital in JIPMER, Pondicherry, India from 2009-2013. We pooled demographic details, clinical presentation, surgical procedure performed and histopathological analysis in these children and adolescent patients from the medical records. Ultrasound was performed for all patients. CA-125, CEA, LDH or $\beta$ hCG had been carried out for all patients. The surgical methods performed and intra operative findings were noted. The histopathological reports were also obtained. All data were analysed using SPSS 16.0 and the results were expressed in percentages.

\section{Results}

57 cases were elective admissions and $7 \%$ were hypothyroid. The age distribution is summarised in Figure 1. Maximum patients were in the age group of 18 years (Figure 1).

The number of post menarchal patients were $50(87 \%)$ and the number of premenarchal patients were $8(13 \%)$ out of the total 58 cases. The most common presentation was pain abdomen (82\%) followed by mass per abdomen (15\%) and menstrual disorders (3\%). The majority of adnexal masses on ultrasound (43.10\%) were in the size range of $5-10 \mathrm{~cm}$ as shown in Table 1.

The origin of adnexal masses was ovarian in $92 \%$ and paraovarian in $8 \%$. The different tumour markers studied were CA-125, CEA, LDH or $\beta$ hCG. Any one of the tumour markers was abnormal only in 7 cases (12\%). Figure 2 summaries all the surgeries performed. Most surgeries were performed on elective basis (98\%) and only one was done as an emergency .Laparoscopic surgery was performed in 13 cases and laparotomy was performed in 45 cases. The most common surgery performed in our study was unilateral salpingoopherectomy (38\%)

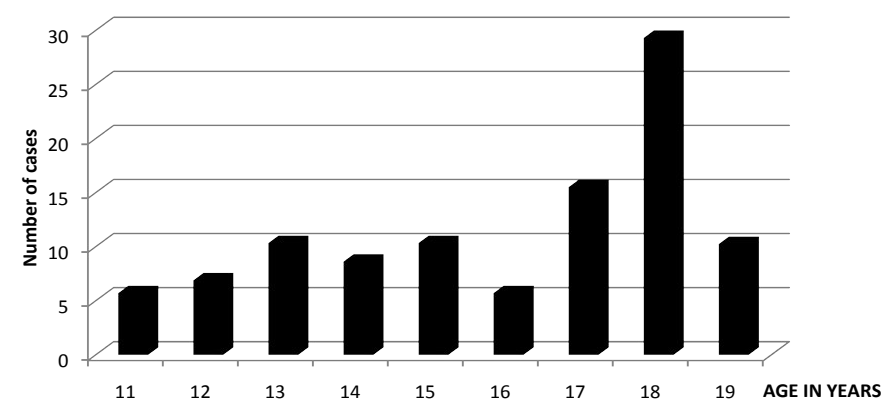

Figure 1. Age distribution in surgically managed adnexal masses in children and adolescents.

Correspondence to: Haritha Sagili, Department of obstetrics and Gynaecology, JIPMER, Pondicherry, India; E-mail: harithasagili@googlemail.com

Received: March 03, 2016; Accepted: April 11, 2016; Published: April 15, 2016 
Table 1. Sizes of adnexal masses.

\begin{tabular}{|c|c|c|}
\hline Size range of tumours in cm & No. of cases & Percentage (\%) \\
\hline $5-10$ & 25 & 43.10 \\
\hline $11-15$ & 10 & 17.94 \\
\hline $16-20$ & 8 & 17.24 \\
\hline $21-25$ & 5 & 8.62 \\
\hline $26-30$ & 5 & 8.62 \\
\hline $31-35$ & 5 & 8.62 \\
\hline
\end{tabular}

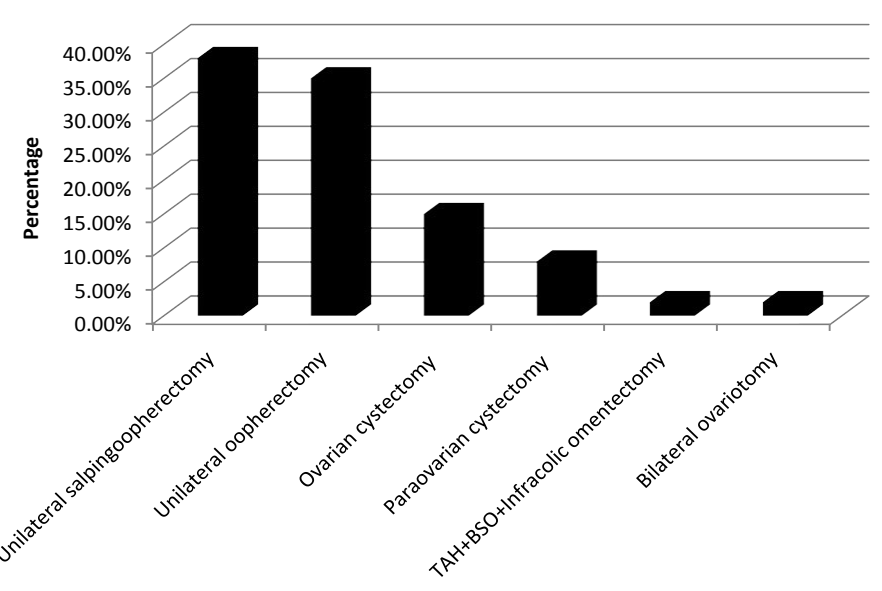

Figure 2. Different surgeries performed in present study.

Table 2. Showing histopathology of adnexal masses.

\begin{tabular}{|l|c|c|c|}
\hline HPE Report & & Number & Percentage (\%) \\
\hline Immature teratoma & $\begin{array}{c}\text { Malignant } \\
\text { neoplastic }\end{array}$ & 2 & 3.44 \\
\hline Serous cystadenoma & Benign neoplastic & 14 & 24.13 \\
\hline Mucinous cystadenoma & & 12 & 20.68 \\
\hline Dermoid cyst & & 7 & 12.06 \\
\hline Paratubal cyst & $\begin{array}{c}\text { Functional non } \\
\text { neoplastic }\end{array}$ & 5 & 8.62 \\
\hline Hemorrhagic cyst & & 10 & 13.79 \\
\hline Simple cyst & & & 17.24 \\
\hline
\end{tabular}

followed by unilateral oopherectomy (35\%), ovarian cystectomy (15\%) and paraovarian cystectomy (8\%). Two girls had bilateral masses and frozen section showed immature teratoma .One girl underwent total abdominal hysterectomy Infracolic omentectomy and other girl had bilateral ovariotomy.

The most common histopathological finding in our study was benign neoplastic lesions, total 33 cases out of 58 cases (57\%) followed by functional lesions in (40\%). The most common non-neoplastic lesion was simple cyst. The malignant tumour found in our cohort was immature teratoma in 2 cases (3\%) (Table 2).

Ovarian torsion was seen in $25 \%$ of cases. One girl was diagnosed with hydatid cyst intraoperatively and was started on Albendazole. Postoperative course was uneventful in all cases.

\section{Discussion}

This retrospective study was carried out with an aim to observe clinical presentation, surgical management and histopathological findings in surgically managed adnexal masses in children and adolescents in our institute. The mean age of presentation in our study was 18 years similar to another Turkey study [2] but higher when compared to datas from China (16 years) $[3,4]$ and Canada (12 years) [5]. The number of premenarchal children in the present study were lower when compared to other studies from China [3] (14.8\%) and Toronto [5] (16.2\%) studies. In our study pain abdomen was the most common symptom similar to other studies [4-6]. But another study [3] found combined symptom of pain and distension of abdomen to be more common (57.7\%). One Pakistan study found the incidence of abdominal pain and mass abdomen to be similar (33.3\% each) in their study [7]. History of sexual contact should be taken and pregnancy should be ruled out in adolescent girls with abdominal pain and adnexal mass [8].

In case of adnexal masses, the initial diagnostic step should be ultrasonography. Doppler is the preferred method of choice for diagnosis of torsion ovary although it has a lesser role in routine examination of adnexal masses. The mean size of the masses in our study was similar to China [3] and Toronto [5] studies.

The role of CA -125/CEA in adolescents is questionable [9] as germ cell tumors are much more common in this age group. In our study either of the tumor markers-LDH, CA-125, CEA or $\beta$ hCG were found to be abnormal in $12 \%$ when compared to other studies. In China study [3], among malignant tumours, $73.7 \%$ had abnormal tumour marker and $20 \%$ of non-tumorous lesion had derranged tumour marker. In Toronto study [5], 27\% of all who underwent surgery had derranged tumour marker. The other tumour markers recommended in this age group include alpha feto protein, inhibin and placental alkaline phosphatase.

The most common surgery performed in our study was unilateral salpingoopherectomy when compared to other studies in which either oophorocystectomy (81\%) [3] or cystectomy [5] (71.6\%) was the most common surgery carried out. Ovarian resection was the most common surgery performed in a study conducted in Tampere university hospital [10]. In another study, $21.3 \%$ of the malignant group underwent TAH+BSO [4]. Radical surgical approach in paediatric age group leads to decrease in future fertility [11] so, in paediatric age group minimal invasive surgery should be tried as much as possible. But, in our study open surgery was performed in 45 cases $(77.58 \%)$ and laparoscopy in $22 \%$ due to lesser laparoscopy surgical expertise. This is in contrast to other studies in which approximately $58 \%$ of the cases had laparoscopic procedure [3,5]. Laparoscopic surgical approach is accepted as gold standard for adnexal mass surgery and has been accepted as the procedure of choice for children and adolescents and is safe and feasible [12,13]. Conventional instruments used for adults can be used successfully in laparoscopic management of adnexal masses in children [12]. Gasless laparoendoscopic single site surgery for adolescents has recently been studied as an alternative to multiport laparoscopic surgery [14]. Lacher also found single -incision paediatricendo-surgery a better alternative to conventional laparoscopy for management of adnexal pathology [15]. Single incision laparoscopic surgery was found to be effective in adolescents with pain abdomen in one study [16].

Ovarian torsion was seen in $25 \%$ of cases in our study which was higher when compared to other studies which varied from 9-20\% [3-5]. Laparoscopic management of ovarian torsion in children and adolescents is recommended [17].

In our study benign neoplastic lesions were the most common adnexal masses followed by non-neoplastic functional masses which are in agreement with other studies [3-5]. One study [11] in contrast reported functional lesions (46.7\%) was most common lesion followed by benign neoplasms (43.1\%) and malignant lesions (3.7\%). 


\section{Conclusion}

A multidisciplinary team of paediatrician, gynaecologist and surgical/medical oncologist are needed to manage adnexal masses to optimize outcome. Fertility preservation should be a goal in the surgical treatment.

\section{References}

1. Hassan E, Creatsas G, Deligeorolgou E, Michalas S (1999) Ovarian tumors during childhood and adolescence. A clinicopathological study. Eur J Gynaecol Oncol 20: 124-126. [Crossref]

2. Dagdeviren H, Cengiz H, Kanawati A, Caypinar SS, Ekin M (2015) Clinical and pathological investigation of adnexal masses in adolescents who underwent surgery in a tertiary center. J Clin Exp Invest 6: 96-101.

3. Liu H, Wang X, Lu D, Liu Z, Shi G (2013) Ovarian masses in children and adolescents in China: analysis of 203 cases. J Ovarian Res 6: 47. [Crossref]

4. Zhang M, Jiang W1, Li G2, Xu C3 (2014) Ovarian masses in children and adolescents - an analysis of 521 clinical cases. J Pediatr Adolesc Gynecol 27: e73-77. [Crossref]

5. Kirkham YA, Lacy JA, Kives S, Allen L (2011) Characteristics and management of adnexal masses in a canadian pediatric and adolescent population. J Obstet Gynaecol Can 33: 935-943. [Crossref]

6. Ryoo U, Lee DY, Bae DS, Yoon BK, Choi D (2010) Clinical characteristics of adnexal masses in Korean children and adolescents: retrospective analysis of 409 cases. $J$ Minim Invasive Gynecol 17: 209-213. [Crossref]

7. Choudry A, Bangash N, Malik A, Choudry H (2008) Adolescent ovarian tumors: a clinicopathlogical review of 15 cases. J Ayub Med Coll Abbottabad 20: 18-21. [Crossref]
8. Zolton JR, Maseelall PB (2013) Evaluation of ovarian cysts in adolescents. Open J Obstet Gynecol 3: 12-16.

9. McCarthy JD, Erickson KM, Smith YR, Quint EH (2010) Premenarchal ovarian torsion and elevated CA-125. J Pediatr Adolesc Gynecol 23: e47-50. [Crossref]

10. Piippo S, Mustaniemi L, Lenko H, Aine R, Mäenpää J (1999) Surgery for ovarian masses during childhood and adolescence: a report of 79 cases. J Pediatr Adolesc Gynecol 12: 223-227. [Crossref]

11. Spinelli C, Buti I, Pucci V, Liserre J, Alberti E, et al. (2012) Adnexal torsion in children and adolescents :new trends to conservative surgical approach-Our experience and review of literature. Gynecol Endocrinol 29: 54-58. [Crossref]

12. Kim HB, Cho HY, Park SH, Park ST (2015) Laparoscopic ovarian surgery in children and adolescents. JSLS 19: e2014. [Crossref]

13. Mayer JP, Bettolli M, Kolberg-Schwerdt A, Lempe M, Schlesinger F, et al. (2009) Laparoscopic approach to ovarian mass in children and adolescents: already a standard in therapy. J Laparoendosc Adv Surg Tech A 19 Suppl 1: S111-115. [Crossref]

14. Takeda A, Imoto S, Nakamura H (2014) Management of pediatric and adolescent adnexal masses by gasless laparoendoscopic single-site surgery. Eur J Obstet Gynecol Reprod Biol 181: 66-71. [Crossref]

15. Lacher M, Kuebler JF, Yannam GR, Aprahamian CJ, Perger L, et al. (2013) Singleincision pediatric endosurgery for ovarian pathology. J Laparoendosc Adv Surg Tech A 23: 291-296. [Crossref]

16. Litz C, Danielson PD, Chandler NM (2014) Single incision laparoscopic surgery for pediatric adnexal pathology. J Pediatr Surg 49: 1156-1158. [Crossref]

17. El-Ebeissy HE, Shalaby R, Helal AAEG (2014) Laparoscopic management of Ovarian Torsion in children and Adolescent. J American Sci 10: 56-61.

Copyright: (C2016 Hembram M. This is an open-access article distributed under the terms of the Creative Commons Attribution License, which permits unrestricted use, distribution, and reproduction in any medium, provided the original author and source are credited. 